\begin{tabular}{|c|c|}
\hline Title & Effects of parabens on apoptosis induced by serum-free medium. \\
\hline Author(s) & Egawa, Mari; A oki, Kentaro; Sun, Y ongkun; Hosokawa, Toshiy uki; Saito, Takeshi; Kurasaki, Masaaki \\
\hline Citation & $\begin{array}{l}\text { Journal of environmental science and health. Part. B, Pesticides, food contaminants, and agricultural wastes, } 47(3), 196- \\
204 \\
\text { https://doi.org/10.1080/03601234.2012.634341 }\end{array}$ \\
\hline Issue Date & 2012-03 \\
\hline Doc URL & http:/hdl.handle.net/2115/52989 \\
\hline Rights & $\begin{array}{l}\text { This is an A uthor's A ccepted Manuscript of an article published in Journal of Environmental Science and Health, Part B } \\
\text { Pesticides, Food Contaminants, and Agricultural W astes, V ol. 47, Iss. 3, 2012, copyright Tay lor \& Francis, available } \\
\text { online at: http:/www.tandfonline.com/10.1080/03601234.2012.634341. }\end{array}$ \\
\hline Type & article (author version) \\
\hline File Information & Ms\#B1471f_BW.pdf \\
\hline
\end{tabular}

Instructions for use 


\section{Effects of parabens on apoptosis induced by serum-freemedium} (1)

${ }^{1}$ Course of Environmental Adaptation Science, Graduate School of Environmental Science, Hokkaido University, Sapporo 060-0810 Japan 8

${ }^{2}$ Higher Education Research and Development Division, Institute for the Advancement of Higher Education Hokkaido University, Sapporo 060-0817 Japan

${ }^{3}$ Faculty of Health Sciences, Hokkaido University, Sapporo 060-0812 Japan

${ }^{4}$ Group of Environmental Adaptation Science, Faculty of Environmental Earth Science, Hokkaido University, Sapporo 060-0810 Japan

\section{ABSTRACT}

(1)

Alkyl esters of $p$-hydroxybenzoic acids (parabens), an endocrine disrupter, are used as preservatives in cosmetics and foods. In this study, to

*Address correspondence to Masaaki Kurasaki, Group of Environmental Adaptation science, Faculty of Environmental Earth Science, Hokkaido University, Sapporo, Japan; Phone: +81-11-706-2243, Fax:+81-11-706-4864; E-mail:kura@ees.hokudai.ac.jp 
understand the relationship between parabens and differentiation in

29 infants, the effects of parabens on apoptosis induced by serum

30 deprivation in PC12 cells were investigated. In addition,

31 apoptosis-related factors were assayed. As results, a tendency toward enhancement of apoptosis was observed in the cells cultured in the serum-free medium with methylparaben, and this tendency was suggested to be related to the contents of Bad. Butylparaben did not show any tendency to enhance apoptosis.

Keywords: PC12 cell, endocrine disrupter, food additives, apoptotic factors, methylparaben, butylparaben

\section{INTRODUCTION}

Parabens, alkyl esters of $p$-hydroxybenzoic acid, are most commonly used as preservatives in foods, cosmetics, toiletries and pharmaceuticals because of their relatively low toxicity in humans and their effective antimicrobial activity. 
47 important requirement for the estrogenic activity of some alkylphenols. ${ }^{[1]}$

48 Parabens are structurally similar to alkylphenols. These compounds exert

49 weak estrogenic activity as described by Lemini et al. ${ }^{[2]}$, Routledge et al.

$50{ }^{[3]}$, Hossaini et al. ${ }^{[4]}$ and Byford et al. ${ }^{[5]}$ The magnitude of the estrogenic

51 response increases with the alkyl group size, as shown by the fact that

52 ethylparaben, propylparaben, and butylparaben are approximately

$53150,000-, 30,000-$ and 10,000 -fold less potent than $17 \beta$-estradiol. ${ }^{[6]}$

54 Some studies have examined the effects of early exposure to

55 environmental toxicants using embryos. ${ }^{[7-8]}$ They reported that exposure

56 to some chemicals increased mortality, induced morphologic

57 deformations, increased apoptosis, and accelerated embryogenesis in the

58 embryo stage. White ${ }^{[9]}$ reported growth effects of methylparaben,

59 propylparaben and EDTA on a femur weight in organ cultures of

60 embryonic chicks. The methylparaben and propylparaben concentrations

61 found to stimulate growth were 0.25 to $2.5 \mu \mathrm{g} / \mathrm{mL}$ and 0.025 to $2.5 \mu \mathrm{g} / \mathrm{mL}$,

62 respectively. These results suggested that parabens might have some

63 effects on infants and embryos. From this viewpoint, there were some

64 interesting reports that endocrine disrupters affected apoptosis in

65 cells. ${ }^{[10-13]}$ 
Apoptosis is a morphological and biochemical description of a

67 physiological cell death mechanism that is commonly associated with programmed events necessary for the differentiation and development of

69 individuals and organs. ${ }^{[14-15]}$ Maroto and Perez-Polo ${ }^{[15]}$ wrote that

although apoptosis is often referred to as programmed cell death, the two

71 terms are not synonymous. Apoptotic events are not programmed but

rather occur in response to environmental cellular signals in many

73 instances. ${ }^{[16]}$ The activation of apoptosis by the signals and its role in

74 organisms need to be studied. Apoptotic cell death is characterized by

75 chromatin condensation, DNA fragmentation and membrane blebbing,

76 resulting in the formation of apoptotic bodies. ${ }^{[14]}$ Apoptosis is regulated

77 and executed by two major protein families, the Bcl-2 and caspase

78 families, which are highly conserved from worms to humans. ${ }^{[17-18]}$ Each

caspase is synthesized as an inactive precursor, which is activated only

80 after a cell has received a death signal. ${ }^{[19]}$ The Bcl-2 family, which is

81 involved in the regulation of caspase activity, is subdivided into

82 pro-apoptotic (for example, Bax and Bad) and anti-apoptotic (for example,

83 Bcl-2) members, which share one or more similar regions. ${ }^{[20-21]}$ However,

84 the influence of parabens on apoptosis in cultured cells has not been 
85 investigated.

86 In rat pheochromocytoma PC12 cells, apoptosis is induced when the cells

87 are cultured in serum-free medium. Apoptotic PC12 cells exhibit DNA

88 fragmentation. ${ }^{[22-23]}$ Thus, these cells have proven to be a useful model

89 for studying the mechanism of induction and inhibition of apoptosis. ${ }^{[15,}$

$90 \quad 24]$

91 In this study, to determine the effects of parabens in differentiation of

92 embryos and infants, their effects on apoptosis induced by serum

93 deprivation were investigated using the PC12 cell system. In addition,

94 apoptotic factors such as caspase-3 and the Bcl-2 family in PC12 cells

95 exposed to parabens were measured by enzyme-linked immunosorbent

96 assay (ELISA) and reverse transcriptase (RT)-PCR.

97

98 MATERIALS AND METHODS

99

$100 \quad$ Materials

101

102 PC12, a rat pheochromocytoma cell line, was purchased from the

103 American Type Culture Collection (USA and Canada). Dulbecco's 
104 modified Eagle's medium (DMEM), streptavidin-conjugated peroxidase,

105 phosphate-citrate buffer with sodium perborate capsules and 106 -phenylendiamine dihydrochloride (OPD) were from Sigma (St. Louis, 107 MO, USA). Fetal bovine serum (FBS) was from HyClone (Rockville, MD, 108 USA). The caspase assay kit, SV total RNA isolation kit, RT-PCR kit and 109 access RT-PCR introductory kit were from Promega (Madison, WI, USA).

110 Methyl p-hydroxybenzoate (methylparaben) and butyl p-hydroxybenzoate 111 (butylparaben) were obtained from Nacalai Tesque (Kyoto, Japan). Biotin 112 16-dUTP, proteinase $\mathrm{K}$ and the blocking reagent were from Roche 113 Diagnostics (Mannheim, Germany). Polyclonal antibodies against Bax, 114 Bad and Bcl-2 were from Oncogene Research Products (Boston, MA, 115 USA) and Santa Cruz Biotechnology (Santa Cruz, CA, USA). The 116 secondary antibody, biotinylated donkey anti-rabbit immunoglobulin, was 117 from Amersham Pharmacia Biotech (Buckinghamshire, UK). The DNA 1187500 assay kit and RNA 6000 Nano Assay kit were from Agilent 119 Technologies (Waldbronn, Germany). Other chemicals were of analytical 120 reagent grade. Methylparaben and butylparaben were dissolved in ethanol 121 and used as the vehicle. 


\section{Cell Culture and Exposure Conditions}

124

125 PC12 cells were maintained in DMEM supplemented with $10 \%$ FBS in a

126 humidified incubator at $37^{\circ} \mathrm{C}$ and $5 \% \mathrm{CO}_{2}$. Inactivation of $\mathrm{FBS}$ was

127 carried out at $56^{\circ} \mathrm{C}$ for $30 \mathrm{~min}$. The cells were preincubated in $25 \mathrm{~cm}^{2}$

128 flasks (Nunc, USA) for two or three days, and then the medium was

129 replaced with serum/serum-free DMEM with or without methylparaben or

130 butylparaben as follows.

131 Cells were incubated in serum-free DMEM, 0, 0.001,0.01,0.1 1 and 10

$132 \mathrm{mg} / \mathrm{mL}$ (final concentration) of methylparaben or butylparaben for one,

133 two and three days. Five $\mu \mathrm{L}$ of a 1000 -fold concentration of

134 methylparaben or butylparaben in ethanol was added to the $5 \mathrm{~mL}$ cell

135 medium. Five microliters of ethanol was added to the serum-free DMEM

136 and DMEM supplemented with $10 \%$ FBS as positive and negative control

137 of apoptosis, respectively. When the medium was changed to

138 serum-deprived medium, cells in the flask were washed twice with

139 serum-free DMEM.

140 Oberdoerster et al. ${ }^{[25]}$ reported that $150 \mathrm{mM}$ ethanol-induced enhancement

141 of cell death by serum deprivation increased the extent of apoptosis in 
142 PC12 cells. Furthermore, Neuman et al. ${ }^{[26]}$ observed that $100 \mathrm{mM}$ ethanol

143 induced apoptosis in cultured skin cells, through $40 \mathrm{mM}$ ethanol rarely

144 affected apoptosis in the cells. Based on these reports, it was presumed

145 that using ethanol at a concentration of $1 \mu \mathrm{L} / \mathrm{mL}$ (approximately $17 \mathrm{mM}$ )

146 in this study did not affect apoptosis in PC12 cells.

148 Nuclear DNA Isolation

149

150 After that the PC12 cells were treated with 0 to $10 \mu \mathrm{g} / \mathrm{mL}$ methylparaben

151 and butylparaben, and $1 \mu \mathrm{L} / \mathrm{mL}$ ethanol as a control for three days. The

152 cells were then harvested using a scraper, and centrifuged at 1,500 rpm

153 for $10 \mathrm{~min}$. Then the supernatants were removed and the cells were

154 washed twice at 1,500 rpm with $10 \mathrm{mM}$ Tris-5 mM HCl containing 150

$155 \mathrm{mM} \mathrm{NaCl}$ for $5 \mathrm{~min}$. The obtained cells were incubated with $10 \mathrm{mM}$ Tris -5

$156 \mathrm{mM} \mathrm{HC1}, 0.1 \mathrm{M}$ EDTA, $0.5 \% \mathrm{SDS}$ and $20 \mu \mathrm{g} / \mathrm{mL}$ pancreatic RNAase for 1

$157 \mathrm{hr}$ at $37^{\circ} \mathrm{C}$. Proteinase $\mathrm{K}$ was added to the suspension up to $100 \mu \mathrm{g} / \mathrm{mL}$,

158 and the enzyme reaction was carried out for $3 \mathrm{hr}$ at $50^{\circ} \mathrm{C}$. After cooling,

159 the nuclear DNA was serially extracted with phenol and chloroform. 
161 Quantification of DNA Fragmentation in PC12 Cells by the

TdT-mediated dUTP-biotin Nick End Labeling (TUNEL) Method

164 The DNA obtained from PC12 cells treated with methylparaben and

165 butylparaben was resuspended in $100 \mathrm{mM}$ Tris-HCl, pH 8.0, containing 1 166 mM EDTA, and equal amounts of DNA were put into 96-well plates.

167 Quantification of DNA fragmentation in PC12 cells was done by the 168 method of Kurasaki et al. ${ }^{[27]}$

\section{ELISA of Apoptotic Factors in PC12 Cells}

172 The PC12 cells were incubated with 0 to $10 \mu \mathrm{g} / \mathrm{mL}$ methylparaben or

173 butylparaben, or $1 \mu \mathrm{L} / \mathrm{mL}$ ethanol as a control for one, two, or three days.

174 After the cultivation, the cells were harvested using a scraper. The harvested cells were washed twice at $1,500 \mathrm{rpm}$ with $10 \mathrm{mM}$ Tris-5 $\mathrm{mM}$

$176 \mathrm{HCl}$ buffer containing $150 \mathrm{mM} \mathrm{NaCl}$ for $5 \mathrm{~min}$. The cells were then resuspended in $10 \mathrm{mM}$ Tris-5 mM HCl buffer containing $150 \mathrm{mM} \mathrm{NaCl}$ 178 and disrupted by sonication for $30 \mathrm{sec}$ with a Sonifier 250 (Branson). The 
179 cell debris and unbroken cells were removed by centrifugation. The

180 contents of $\mathrm{Bad}, \mathrm{Bax}$ and $\mathrm{Bcl}-2$ in the cells were measured by the method

181 of Yamanoshita et al. ${ }^{[12]}$ The cell extracts after incubation with parabens

182 were adjusted to equal protein concentrations with $40 \mathrm{mM}$ Tris-5, $\mathrm{mM}$

$183 \mathrm{HCl}$ containing $150 \mathrm{mM} \mathrm{NaCl}$ for ELISA. The primary antibody for $\mathrm{Bad}$,

184 Bax or Bcl-2 (diluted 1:250 with $1 \%[\mathrm{v} / \mathrm{v}]$ blocking reagent in the same

185 buffer) was reacted with antigens for $1 \mathrm{hr}$. The contents of the three

186 factors were calculated from the absorbance measured at $405 \mathrm{~nm}$ with a

187 Microplate Reader model 450 (BIO-RAD).

188

$189 \quad$ RNA Isolation

190

191 The total RNA of PC-12 cells treated with methylparaben or butylparaben

192 was extracted using an SV total RNA isolation kit according to the

193 instruction manual after the cells were treated with parabens. The details

194 are described in the legend of Figure 5. The total RNA obtained was

195 verified using a RNA 6000 Nano Assay kit with an Agilent 2100 Bio

196 Analyzer. Total RNA was stored at $-20^{\circ} \mathrm{C}$ until use for one or two days. 


\section{Gene Expression by RT-PCR}

199

200 Expression of bad, bax and bcl-2 mRNAs, in the PC12 cells exposed to

201 parabens was detected using the Access RT-PCR kit and Access RT-PCR

202 introductory kit according to the manufacturer's instructions. The PCR

203 primers of bad, bax, bcl-2 and $\beta$-actin were designed from their DNA

204 sequences. ${ }^{[28]}$ The samples were heated at $48^{\circ} \mathrm{C}$ for $45 \mathrm{~min}$ and

205 subsequently at $94^{\circ} \mathrm{C}$ for $2 \mathrm{~min}$ for enzyme reaction. The time course of

206 one cycle was $94^{\circ} \mathrm{C}$ for $30 \mathrm{~s}$ for denaturation, $60^{\circ} \mathrm{C}$ for $\beta$-actin and bax,

$20755^{\circ} \mathrm{C}$ for bad and $47^{\circ} \mathrm{C}$ for bcl-2 for $1 \mathrm{~min}$ for annealing, and $68^{\circ} \mathrm{C}$ for 2

208 min for extension. The number of cycles performed was 30 or 40 . $\beta$-Actin

209 was chosen as an internal control. PCR products were verified using a

210 DNA 7500 Assay kit with a 2100 Bio Analyzer (Agilent Technologies,

211 USA) according to the manufacturer's instructions.

212

213 Measurement of Caspase-3 Like Activity

214

215 PC12 cells were incubated in the medium containing a caspase inhibitor,

216 Z-VAD or Z-VAD-free medium with 0 to $10 \mu \mathrm{g} / \mathrm{mL}$ methylparaben or 1 
$217 \mu \mathrm{L} / \mathrm{mL}$ ethanol as a control for two days. The activity of caspase-3-like

218 protease was detected using the Caspase Assay System kit. The activity of

219 caspase-3 like protease in the PC12 cells was indirectly measured as

220 absorbance at $405 \mathrm{~nm}$ depending on the pNA released from the cleaved

221 substrate. After overnight incubation, absorbance at $405 \mathrm{~nm}$ was

222 measured as the caspase-3 like activity

223

224 Statistical Analysis

225

226 Each value is expressed as mean \pm SEM. Analysis of variance (ANOVA)

227 followed by the Bonferroni/Dunn multicomparison test was employed.

228 Statistical analyses were performed using StatView (HULINKS, Tokyo,

229 Japan).

230

231 RESULTS

232

233 Effects of Methylparaben and Butylparabenon Apoptosis

234

235 To study the effects of methylparaben and butylparaben on apoptosis, 
236 TUNEL signals from nuclear DNA in PC12 cells cultured in serum-free

237 medium and treated with $0.001,0.01,0.1,1$ and $10 \mu \mathrm{g} / \mathrm{mL}$ methylparaben 238 or butylparaben for three days were measured (Fig. 1).

239 The TUNEL signals in the cells cultured in the serum-deprived medium 240 were significantly increased as compared with those in the control cells.

241 The signals in the DNA of the cells treated with methylparaben showed a 242 tendency to increase (Fig. 1a). On the other hand, TUNEL signals in the 243 cells treated with butylparaben at various concentrations showed no 244 significant differences (Fig. 1b).

245 These changes did not show the dose-response effect. However these 246 kinds of irregular responses were showed in similar experiments. ${ }^{[13,29]}$

248 Contents of Apoptotic Factors Measured by ELISA

250 To understand the reason for the different tendencies of TUNEL signals

251 between the PC12 cells treated with methylparaben and butylparaben, the

252 contents of the apoptotic factors Bad, Bax and Bcl-2 in the PC12 cells

253 cultured in serum-free medium containing $0.001,0.01,0.1,1$ or $10 \mu \mathrm{g} / \mathrm{mL}$ 254 methylparaben or butylparaben for one, two or three days, were measured 
by ELISA (Figs. 2-4).

256 After one-day exposure, the contents of Bad increased according to the

257 increase in the concentration of methylparaben as expected (Fig. 2a). Bad

258 contents in the cells exposed to 0.1 and $10 \mu \mathrm{g} / \mathrm{mL}$ methylparaben for one

259 day increased significantly $(P<0.05)$. After two days of exposure, the

260 contents of Bad increased slightly in the cells treated with methylparaben

261 (Fig. 2b). Bad contents increased significantly $(\mathrm{P}<0.05)$ in cells treated

262 with $1 \mu \mathrm{g} / \mathrm{mL}$ methylparaben for two days. Unexpectedly, however, there

263 was no significant difference among Bad contents in cells treated with the

264 various concentrations of methylparaben for three days (Fig. 2c).

265 There was no significant difference among Bad contents in the cells

266 treated with butylparaben for one, two or three days at the various

267 concentrations as expected (Figs. 2d-f).

268 In addition, there was no significant difference among Bax contents in the

269 cells treated with methylparaben or butylparaben for one, two or three

270 days at the various concentrations (Fig. 3 ).

271 Bcl-2 contents in the cells exposed to $0.1 \mu \mathrm{g} / \mathrm{mL}$ methylparaben for one

272 day increased significantly $(\mathrm{P}<0.05$; Fig. 4a). However, there was no

273 significant difference among Bcl-2 contents in the cells treated with 
274 methylparaben for two and three days at the various concentrations (Figs.

$2754 \mathrm{~b}$ and $\mathrm{c})$.

276 There was no significant difference among Bcl-2 contents in the cells

277 treated with butylparaben for one, two or three days at the various

278 concentrations (Figs. 4d-f).

279

280 Expression of Apoptotic Factor mRNAs Detected by RT-PCR

281

282 To verify changes of apoptotic factors in PC12 cells treated with

283 methylparaben or butylparaben, the expression of bad, bax and bcl-2

284 mRNAs in PC12 cells cultured in the serum-free medium with $0.001,0.01$,

$2850.1,1$ or $10 \mu \mathrm{g} / \mathrm{mL}$ methylparaben or butylparaben added for one, two or

286 three days, was measured by RT-PCR.

287 There was a tendency for the expression of bad mRNA to increase in the 288 cells treated with methylparaben after one day similar to the changes of

289 Bad contents detected by ELISA in the cells treated with methylparaben

290 for one and two days (Figs. 5a and b). There was no significant difference

291 of bad mRNA expression among cells treated with methylparaben for two

292 and three days at the various concentrations (Fig. 5c), the same as seen in 
293 Figure 2C. After one- and two-day exposures, there was a tendency for

294 the bad mRNA in the cells treated with butylparaben to increase (Figs. $5 \mathrm{~d}$

295 and e). There was no significant difference of bad mRNA expression

296 among the cells treated with butylparaben for three days at 0.001 to 1

$297 \mu \mathrm{g} / \mathrm{mL}$ (Fig. 5f). However the cells died as a result of treatment with 10

$298 \mu \mathrm{g} / \mathrm{mL}$ butylparaben for two and three days (Figs. 5e and f).

299 There was no significant difference among bax and bcl-2 mRNAs in the

300 cells treated with methylparaben or butylparaben for one, two or three

301 days at the various concentrations (data not shown).

302

303 Measurement of Caspase-3 Like Activity

304

305 To investigate whether apoptosis-related factors under the conditions of

306 apoptosis induced by serum deprivation were changed by addition of

307 methylparaben, caspase-3 activity was measured in PC12 cells cultured in

308 serum-free medium containing methylparaben (Fig. 6). The caspase-3 like

309 activity in the cells increased with increasing concentrations of

310 methylparaben as expected. On the other hand the activity in the cells did

311 not change with buthylparaben (data not shown). 


\section{DIS C USS I O N}

315 The aim of this experiment was to study effects of parabens on apoptosis

316 induced in advance. PC12 cells are well known to be a useful model for

317 studying the mechanisms of induction and inhibition of apoptosis under

318 conditions with and without serum, because apoptosis is induced by serum

319 deprivation in the cells. In our laboratory the influence of endocrine

320 disrupters on apoptosis induced by serum deprivation has been

321 investigated using PC12 cells. ${ }^{[12-13,30]}$ When serum is present, apoptosis

322 was not induced by addition of parabens (data not shown). This means

323 that parabens cannot induce apoptosis itself. On the other hand, under

324 serum deprivation, a tendency for apoptosis to be induced occurred after

325 addition of methylparaben in the in vitro model system described above

326 (Fig. 1a). This means that there is a possibility for enhancement of

327 apoptosis by addition of methylparaben. In this study serum was used as a

328 regulatory factor for apoptosis. The any tendency for apoptosis to be

329 induced by serum deprivation did not show in the cells treated with

330 various concentrations of butylparaben (Fig. 1b). 
331 It was reported that the binding of parabens to the estrogen $\alpha$-receptor

$332($ ER $\alpha)$ of MCF7, human breast cancer cells, increased with increasing

333 alkyl chain length. ${ }^{[5]}$ Moreover, the estrogenic activity of parabens has

334 been demonstrated to increase with increasing length of the linear alkyl

335 chain from methylparaben to butylparaben. ${ }^{[1]}$ In addition, $4 \times 10^{-4} \mathrm{M}$

336 methylparaben and $3 \times 10^{-6} \mathrm{M}$ buthylparaben showed $10 \%$ of the activity

337 of $10^{-7} \mathrm{M} 17-\beta$ estradiol. These concentrations of parabens are more than

338 ten $\mathrm{mg} / \mathrm{mL}$. However, in the present study, the TUNEL signals showed no

339 relationship between alkyl group size and effects on apoptosis in PC12

340 cells treated with parabens (Figs. 1a and b). From the results, it was

341 indicated that the effects of parabens on apoptosis in the cells were

342 independent of the function of ER $\alpha$. because PC12 is an ER $\alpha$-negative cell

343 line.

344 To study whether enhancement of apoptosis by treatment with

345 methylparaben or butylparaben was regulated by the apoptotic factors Bax,

346 Bad and Bcl-2, we measured the relative contents of these apoptotic

347 factors in PC12 cells treated with methylparaben or butylparaben under

348 serum-free conditions using ELISA and RT-PCR. The content of Bad, a

349 pro-apoptotic protein, was slightly increased with increasing 
concentrations of methylparaben for one day (Fig. 2a). However, no

351 significant effects were seen on the expression of bad mRNA, although

352 there was a tendency toward an increase after one-day exposure. No

353 changes were observed in the contents of Bax and Bcl-2 under the same

354 conditions. These results could indicate that the enhancement of

355 apoptosis in the PC12 cells cultured in serum-free medium containing

356 methylparaben could be associated with an increase of Bad content.

357 Moreover, caspase-3 activity was increased in the cells treated with 0.001

358 to $10 \mu \mathrm{g} / \mathrm{mL}$ methylparaben (Fig. 6). It was considered that the

359 enhancement of apoptosis in the PC12 cells treated with methylparaben

360 was mediated by the caspase-3 pathway.

361 Paraben-induced cytotoxicity has been speculated to depend not only on

362 the dose of paraben, but also on the length of the exposure period.

363 However, the contents of the apoptotic factors in the cells treated with

364 parabens differed markedly at one day as compared with those for two and

365 three days. Maroto and Peres-Polo ${ }^{[15]}$ reported that expression of Bad and

366 Bax was decreased by serum deprivation for $3 \mathrm{hr}$ and $24 \mathrm{hr}$ in PC12 cells.

367 However, in this study, the tendency for Bad contents to increase in cells

368 treated with methylpareben was only observed on day one, although the 
contents of Bax and Bcl-2 showed no changes under the same conditions

370 for one to three days.

371 In this study, PC12 cells died after the treatment with butylparaben at 10 $372 \mu \mathrm{g} / \mathrm{mL}\left(5.15 \times 10^{-5} \mathrm{M}\right)($ Figs. $5 \mathrm{e}-\mathrm{f})$. Darbre et al. [31] reported that benzylparaben was cytotoxic at a concentration of $10^{-4} \mathrm{M}$ for

374 ER $\alpha$-negative MDA-MB-231 human breast cells. On the other hand, 375 metylparaben showed cytotoxicity at about $400 \mu \mathrm{g} / \mathrm{mL}$ in human THP-1

376 cells. ${ }^{[32]}$ With the experimental concentration (maximum $10 \mu \mathrm{g} / \mathrm{mL}$ ) in 377 this study, metylparaben did not show any cytotoxicity.

378 Janjua et al. ${ }^{[33]}$ reported that butylparaben peaked in serum after a few 379 hours, reaching $81 \mu \mathrm{g} / \mathrm{L}$ after daily whole-body topical application of a 2 $380 \mathrm{mg} / \mathrm{cm}^{2}$ basic cream formulation $(2 \%[\mathrm{w} / \mathrm{w}])$ for two weeks. In addition, 381 five days after the treatment about $20 \mu \mathrm{g} / \mathrm{L}$ butylpareben remained in the 382 serum. Gelb et al. [34] investigated effects of intravenously administered 383 methylparaben on cerebral blood flow in the human brain. They reported 384 that the concentration of methylparaben in serum was more than $30 \mu \mathrm{g} / \mathrm{L}$. 385 On the basis of these reports, the concentrations of methylparaben and 386 butylparaben used in this study were in the expected range in human 387 blood after uptake of the materials containing parabens. 
388 In this study, to investigate the effects of parabens on differentiation and

389 development, the relationship between apoptosis induced by serum 390 deprivation in PC12 cells and parabens was studied. Apoptosis is a 391 physiological cell death mechanism that is commonly associated with 392 programmed events necessary for the differentiation and development of 393 individuals and organs.[14-15] We found that there was no significant 394 effect of parabens on induced apoptosis in PC12 cells. However, 395 methylparaben showed a tendency to enhance of apoptosis (Fig. 1). In 396 addition, methylparaben slightly increased the contents of Bad (Fig. 2) 397 and caspase-3 activity (Fig. 6), thereby possibly further enhancing the 398 apoptosis induced by the serum deprivation. As parabens are hydrophobic 399 compounds, they can be transferred from the maternal body to infants. ${ }^{[7-8]}$

\section{CONCLUSION}

403 From the results, a tendency toward enhancement of apoptosis was

404 observed in the cells cultured in the serum-free medium with 405 methylparaben, and this tendency was suggested to be related to the 406 contents of Bad. Butylparaben did not show any tendency to enhance 
407 apoptosis. Exposure to trace levels of some chemicals increases

408 morphologic deformations and caused adverse effects on embryogenesis

409 in the embryo stage. The human population is chronically exposed to

410 parabens through many thousands of foods, drugs and cosmetic products.

411 From this viewpoint, to clarify the detailed effects of long-term exposure

412 to parabens, further investigation is needed.

413

414 ACKNOWLEDGMENTS

415

416 This research was supported by Grants-in-Aid from the Japan Society for

417 the Promotion of Science (No.18404004 for Kurasaki and No.18590548

418 for Hosokawa). The authors wish to thank Ms. Tomoe Sato, Ms. Miyako

419 Komori and Ms. Ikumi Yanagiuchi for their technical assistance.

420 


\section{REFERENCES}

423 [1] Nishihara, T.; Nishikawa, J.; Kanayama, T.; Dakeyama, F.; Saito, K.; 424 Imagawa, M.; Takatori, S.; Kitagawa, Y.; Hori, S.; Utsumi, H. 425 Estrogenic activities of 517 chemicals by yeast two-hybrid assay. J. 426 Health Sci. 2000, 46(2), 282-298.

427 [2] Lemini, C.; Silva, G.; Timossi, C.; Luque, D.; Valverde, A.; 428 Gonzalez-Martines, M.; Hernandes, A.; Rubio-Poo, C.; Chavez Lara, 429 B.; Valenzuela, F. Estrogenic effects of p-hydroxybenzoic acid in CD 1 430 mice. Environ. Res. 1997, 75(2), 130-134.

431 [3] Routledge, E.J.; Parker, J.; Odum, J.; Ashby, J.; Sumpter, J.P. Some 432 alkyl hydroxy benzoate preservatives (parabens) are estrogenic. 433 Toxicol. Appl. Pharmacol. 1998, $153(1), 12-19$.

434 [4] Hossaini, A.; Larsen, J.J.; Larsen, J.C. Lack of oestrogenic effects of 435 food preservatives (parabens) in uterotrophic assays. Food Chem. 436 Toxicol. 2000, 38(4), 319-323.

437 [5]Byford, J.R.; Shaw, L.E.; Drew, M.G.; Pope, G.S.; Sauer, M.J.; Daubre, 438 P.D. Oestrogenic activity of parabens in MCF7 human breast cancer 439 cells. J. Steroid. Biochem. Mol. Biol. 2002, 80(1), 49-60.

440 [6] Oishi, S. Effects of propyl paraben on the male reproductive system. 441 Food Chem. Toxicol. 2002, 40(12), 1807-1813.

442 [7] Leach, R.E.; Stachecki, J.J.; Armant, D.R. Development of in vitro 443 fertilized mouse embryos exposed to ethanol during the 444 preimplantation period: accelerated embryogenesis at subtoxic levels. $445 \quad$ Teratology 1993, 47(1), 57-64.

446 [8] Bevan, C.L.; Porter, D.M.; Prasad, A.; Howard, M.J.; Henderson, L.P. 447 Environmental estrogens alter early development in Xenopus laevis. 448 Environ. Health Perspect. 2003, 111(4), 488-496. 
[9] White, A.A. Stimulation of the growth of organ cultures by methyl and propyl parabens. Proc. Soc. Exp. Biol. Med. 1967, $126(2), 588-591$.

[10] Aw, T.Y.; Nicotera, P.; Manzo, L.; Orrenius, S. Tributyltin stimulates apoptosis in rat thymocytes. Arch. Biochem. Biophys. 1990, $283(1), 46-50$.

[11] Heimler, I.; Rawlins, R.G.; Owen, H.; Hutz, R.J. Dioxin perturbs, in a dose- and time-dependent fashion, steroid secretion, and induces apoptosis of human luteinized granulosa cells. Endocrinology 1998, $139(10), 4373-4379$.

[12] Yamanoshita, O.; Kurasaki, M.; Saito, T.; Takahasi, K.; Sasaki, H.; Hosokawa, T.; Okabe, M.; Mochida, J.; Iwakuma, T. Diverse effect of tributyltin on apoptosis in PC12 cells. Biochem. Biophys. Res. Commun. 2000, 272(2), 557-562.

[13] Yamanoshita, O.; Saito, T.; Takahashi, K.; Hosokawa, T.; Okabe, M.; Ito, K.; Kurasaki, M. 2,4,5-Trichloro-phenoxyacetic acid inhibits apoptosis in PC12 cells. Life Sci. 2001, 69(4), 403-408.

[14] Kerr,J.F.; Wyllie, A.H.; Currie, A.R. Apoptosis: a basic biological phenomenon with wide-ranging implications in tissue kinetics. Br. J. Cancer 1972, 26(4), 239-257.

[15] Maroto, R.; Perez-Polo, J.R. BCL-2-related protein expression in apoptosis: oxidative stress versus serum deprivation in PC12 cells. J. Neurochem. 1997, 69(2), 514-523.

[16] Barr, P.J.; Tomei, L.D. Apoptosis and its role in human disease. Biotech. 1994, 12(5), 487-493.

[17] Aravind, L.; Dixit, V.M.; Koonin, E.V. The domains of death: evolution of the apoptosis machinery. Trends Biochem. Sci. 1999, $24(2), 47-53$.

[18] Spanos, S.; Rice, S.; Karagiannis, P.; Taylor, D.; Becker, D.L.; 
Winston, R.M.L; Hardy, K. Caspase activity and expression of cell death genes during development of human preimplantation embryos. Reproduction 2002,124(3), 353-363.

480 [19] Nagata, S. Apoptotic DNA fragmentation. Exp. Cell. Res. 2000, $256(1), 12-18$.

[20] Tsujimoto, Y.; Shimizu, S. Bcl-2 family: life-or-death FEBS Lett $2000,466(1), 6-10$.

[21] Adams, J.M.; Cory, S. Life-or-death decisions by the Bcl-2 protein family. Trends Biochem. Sci. 2001, 26(1), 61-66.

[22] Batistatou, A.; Greene, L.A. Aurintricarboxylic acid rescues PC12 cells and sympathetic neurons from cell death caused by nerve growth factor deprivation: correlation with suppression of endonuclease activity. J. Cell Biol. 1991, $115(2), 461-471$.

[23] Batistatou, A.; Greene, L.A. Internucleosomal DNA cleavage and neuronal cell survival/death. J. Cell Biol. 1993, $122(3), 523-532$.

[24] Gollapudi, L.; Oblinger, M.M. Stable transfection of PC12 cells with estrogen receptor (ER ): protective effects of estrogen on cell survival after serum deprivation. J. Neurosci. Res. 1999, 56(1), 99-108.

[25] Oberdoerster, J.; Kamer, A.R.; Rabin, R.A. Differential effect of ethanol on PC12 cell death. J. Pharmacol. Exp. Ther. 1998, 287(1), $359-365$.

[26] Neuman, M.G.; Haber, J.A.; Malkiewicz, I.M.; Cameron, R.G.; Katz, G.G.; Shear, N.H. Ethanol signals for apoptosis in cultured skin cells. Alcohol 2002, 26(3), 179-190.

[27] Kurasaki, M.; Aoki, M.; Miura, T.; Seki, S.; Toriumi, S.; Hosokawa, T.; Okabe, M.; Numata, T.; Saito, S.; Saito, T. A developed method of terminal deoxynucleotidyl transferase system for quantification of DNA damage caused by apoptosis. Anal. Sci. 2001, 17(supp1.), 
i1517-1520.

506

507

508

509

510

511

512

513

514

515

516

517

518

519

520

521

522

523

524

525

526

527

528

529

530

531

532

[28] Kawakami, M.; Inagawa, R.; Hosokawa, T.; Saito, T.; Kurasaki, M. Mechanism of apoptosis induced by copper in PC12 cell. Food Chem. Toxicol. 2008, 46(6), 2157-2164.

[29] Aoki, K.; Egawa, M.; Saito, T.; Hosokawa, T.; Kurasaki, M. Effects of -hexachlorocyclohexane on apoptosis induced by serum deprivation in PC12 cells. J. Environ. Sci. Health Part B 2008, 43(6), $471-475$.

[30] Aoki M, Kurasaki M, Saito T, Seki S, Hosokawa T, Takahashi Y, Fujita H, Iwakuma, T (2004) Nonylphenol enhances apoptosis induced by serum deprivation in PC12 cells. Life Sci 74:2301-2312.

[31] Darbre, P.D.; Byford, J.R.; Shaw, L.E.; Hall, S.; Coldham, N.G.; Pope, G.S.; Sauer, M.J. Oestrogenic activity of benzylparaben. J. Appl. Toxicol. 2003, 23(1), 43-51.

[32] Sakaguchi, H.; Miyazawa, M.; Yoshida, Y.; Ito, Y.; Suzuki, H. Prediction of preservative sensitization potential using surface marker CD86 and/or CD54 expression on human cell line, THP-1. Arch. Dermatol. Res. 2007, 298(9), 427-437.

[33] Janjua, N.R.; Mortensen, G.K.; Andersson, A.M.; Kongshoj, B.; Skakkebaek, N.E.; Wulf, H.C. Systemic Uptake of Diethyl Phthalate, Dibutyl Phthalate, and Butyl Paraben Following Whole-Body Topical Application and Reproductive and Thyroid Hormone Levels in Humans. Environ. Sci. Technol. 2007, 41(15), 5564-5570.

[34] Gelb, A.W.; Gignac, E.; Manninen, P.H.; Farrar, J.K.; Lee, D.H. Methylparaben and propylparaben do not alter cerebral blood flow in humans. Can. J. Anaesth. 1992, 39(7), 691-694. 
Figure 1. Effects on DNA fragmentation in PC12 cells treated with methylparaben $(a ; n=6)$ or butylparaben $(b ; n=5)$ for three days. The

537 TUNEL signals of DNA fragmentation are presented as relative 538 percentages against those of cells cultured in serum-free medium 539 containing $1 \mu \mathrm{L} / \mathrm{mL}$ ethanol. Asterisks denote values significantly 540 different $(* * \mathrm{P}<0.05)$ or having a tendency to be different $(* \mathrm{P}<0.1)$ from 541 cells incubated with serum-free medium without parabens. (mean \pm SEM)

543 Figure 2. Contents of Bad in PC12 cells treated with methylparaben (a, b, 544 c) or butylparaben (d, e, f) for one (a, d), two (b, e) and three (c, f) days. 545 The contents of Bad are presented as relative percentages against those of 546 cells cultured in serum-free medium containing $1 \mu \mathrm{L} / \mathrm{mL}$ ethanol for one 547 day. The mean \pm SEM was calculated four (a, b, c) and five (d, e, f) 548 independent experiments. Asterisks denote values significantly different 549 $(* * \mathrm{P}<0.05)$ from these of cells incubated in serum-free medium without 550 paraben.

Figure 3. Contents of Bax in PC12 cells treated with methylparaben $(a, b$, c) or butylparaben $(\mathrm{d}, \mathrm{e}, \mathrm{f})$ for one $(\mathrm{a}, \mathrm{d})$, two $(\mathrm{b}, \mathrm{e})$ and three $(\mathrm{c}, \mathrm{f})$ days.

554 The contents of Bax are presented as relative percentages against those of cells cultured in serum-free medium containing $1 \mu \mathrm{L} / \mathrm{mL}$ ethanol for one 556 day. The mean \pm SEM was calculated four (a, b, c) and five (d, e, f) 557 independent experiments.

559 Figure 4. Contents of Bcl-2 in PC12 cells treated with methylparaben (a, 560 b, c) or butylparaben (d, e, f) for one (a, d), two (b, e) and three (c, f) 
561 days. The contents of $\mathrm{Bcl}-2$ are presented as a relative percentage against 562 those of cells cultured in serum-free medium containing $1 \mu \mathrm{L} / \mathrm{mL}$ of 563 ethanol for one day. The mean \pm SEM was calculated for four $(a, b, c)$ and 564 five (d, e, f) independent experiments. Asterisk denotes a value 565 significantly different $(* * \mathrm{P}<0.05)$ from cells incubated in serum-free 566 medium without parabens.

568 Figure 5. Contents of bad mRNA in PC12 cells treated with 0 to $10 \mu \mathrm{g} / \mathrm{mL}$ 569 methylparaben (a, b, c) or butylparaben (d, e, f) for one (a, d), two (b, e) 570 and three (c, f) days. The contents of bad mRNA are presented as relative 571 percentages against those of cells cultured in medium containing serum 572 and $1 \mu \mathrm{L} / \mathrm{mL}$ ethanol. The mean \pm SEM was calculated from three (one 573 day) and five (two and three days) independent experiments.

575 Figure 6. The specific activity of caspase-3 in PC12 cells treated with 5760.001 to $10 \mu \mathrm{g} / \mathrm{mL}$ methylparaben and serum deprivation for two days. 577 The specific activity of caspase-3 is presented as a relative value against 578 that of the cells cultured in medium containing serum and $1 \mu \mathrm{L} / \mathrm{mL}$ 579 ethanol as a control. The values are means from two representative 580 experiments. 
Fig.1

- serum + ethanol

$\square$ serum-free + ethanol (Control)

$\square$ serum-free + parabens

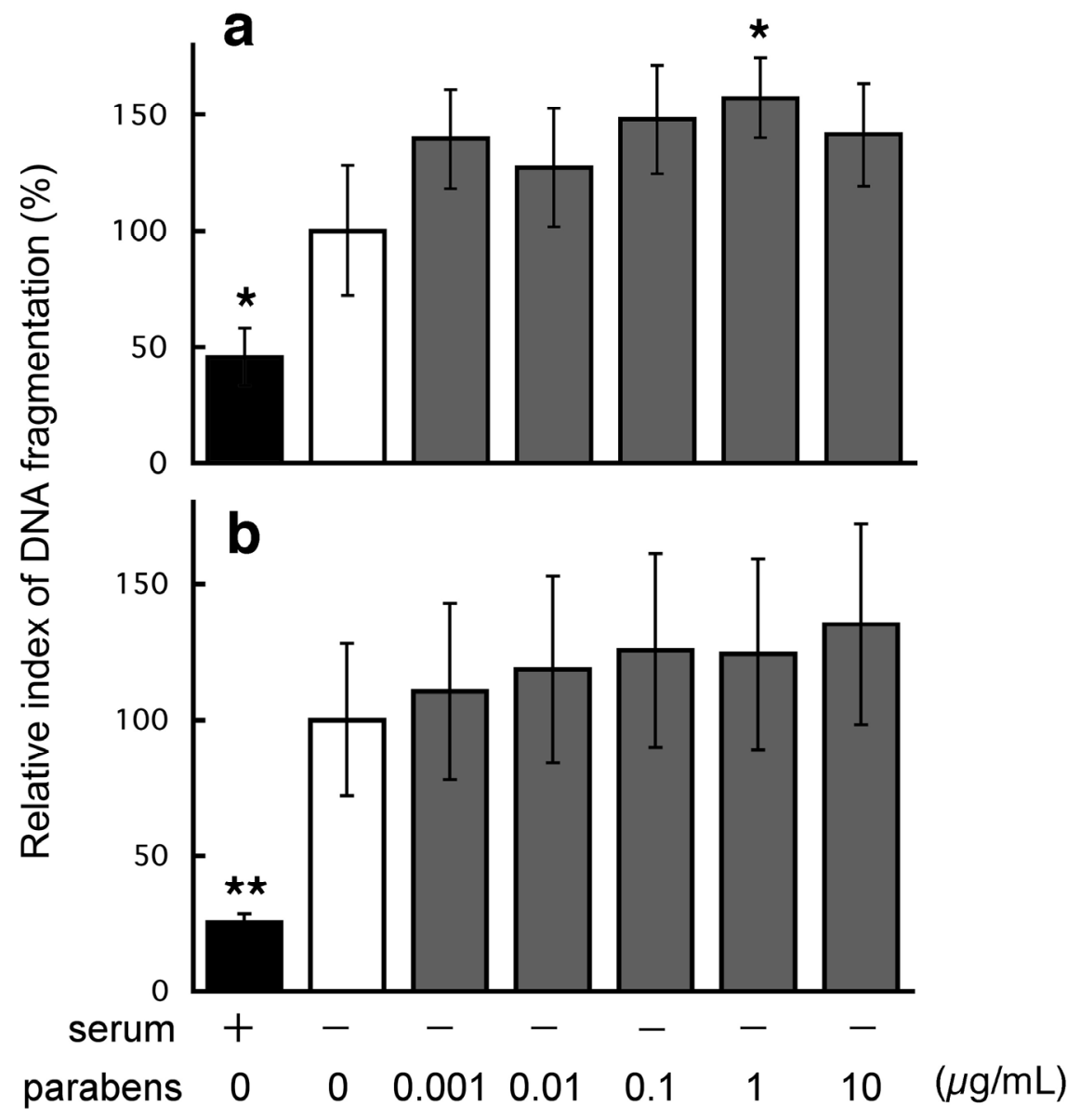

589

590

591

592

593

594

595

596

597

598

599

600 
Fig.2

a serum + ethanol

$\square$ serum-free + ethanol (Control)

$\square$ serum-free + parabens
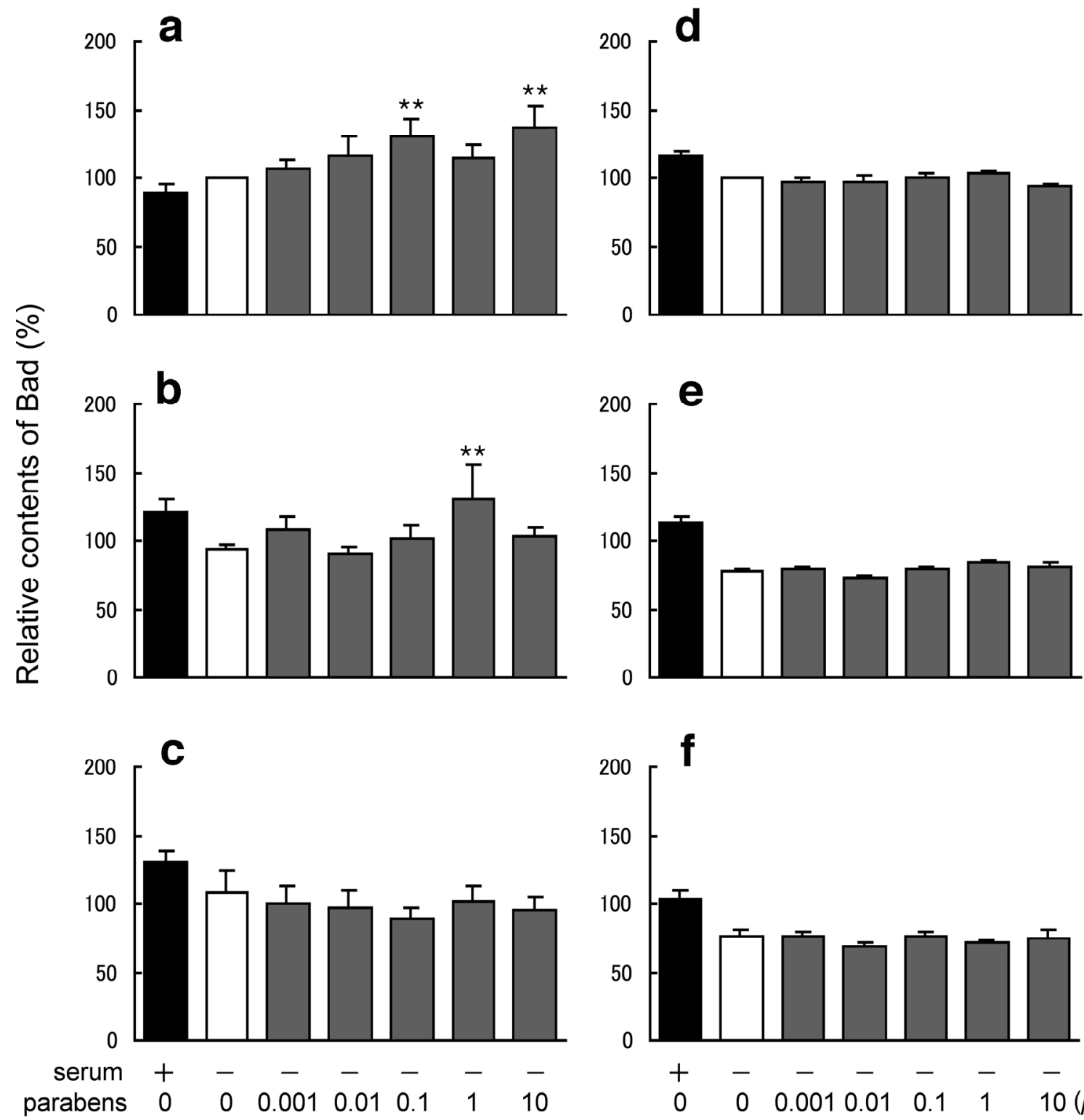

601

$\begin{array}{llllllll}\text { parabens } & 0 & 0 & 0.001 & 0.01 & 0.1 & 1 & 10\end{array}$

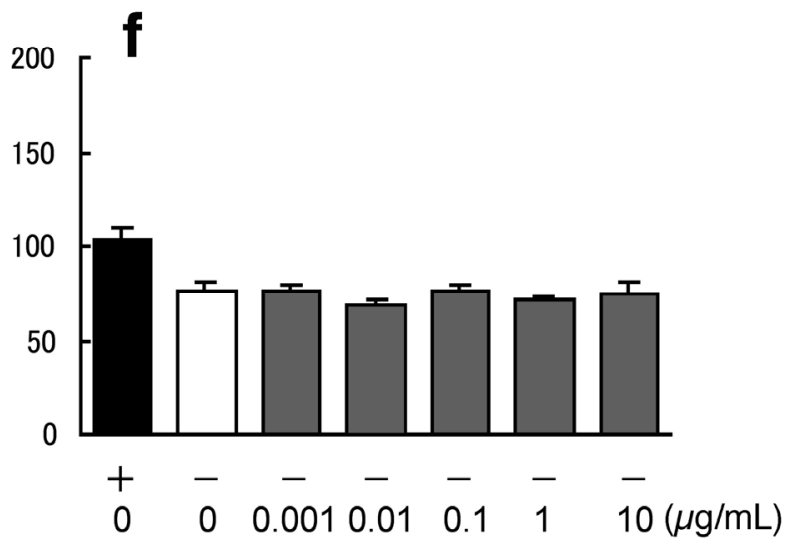

602

603

604

605

606

607

608 
Fig.3

- serum + ethanol

$\square$ serum-free + ethanol (Control)

$\square$ serum-free + parabens
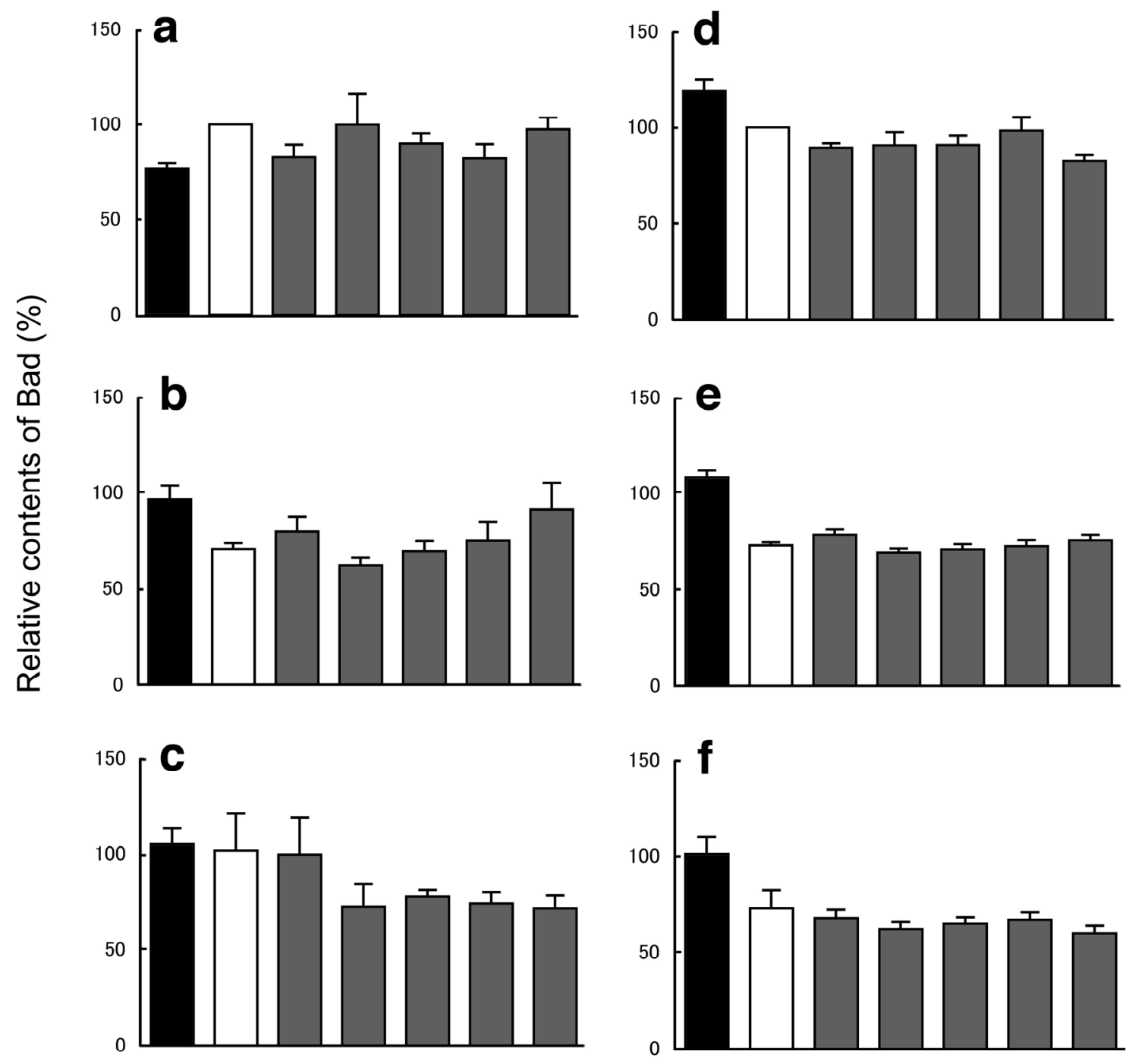

610

611

612

613

614

615

616 
Fig.4

- serum + ethanol

$\square$ serum-free + ethanol (Control)

$\square$ serum-free + parabens
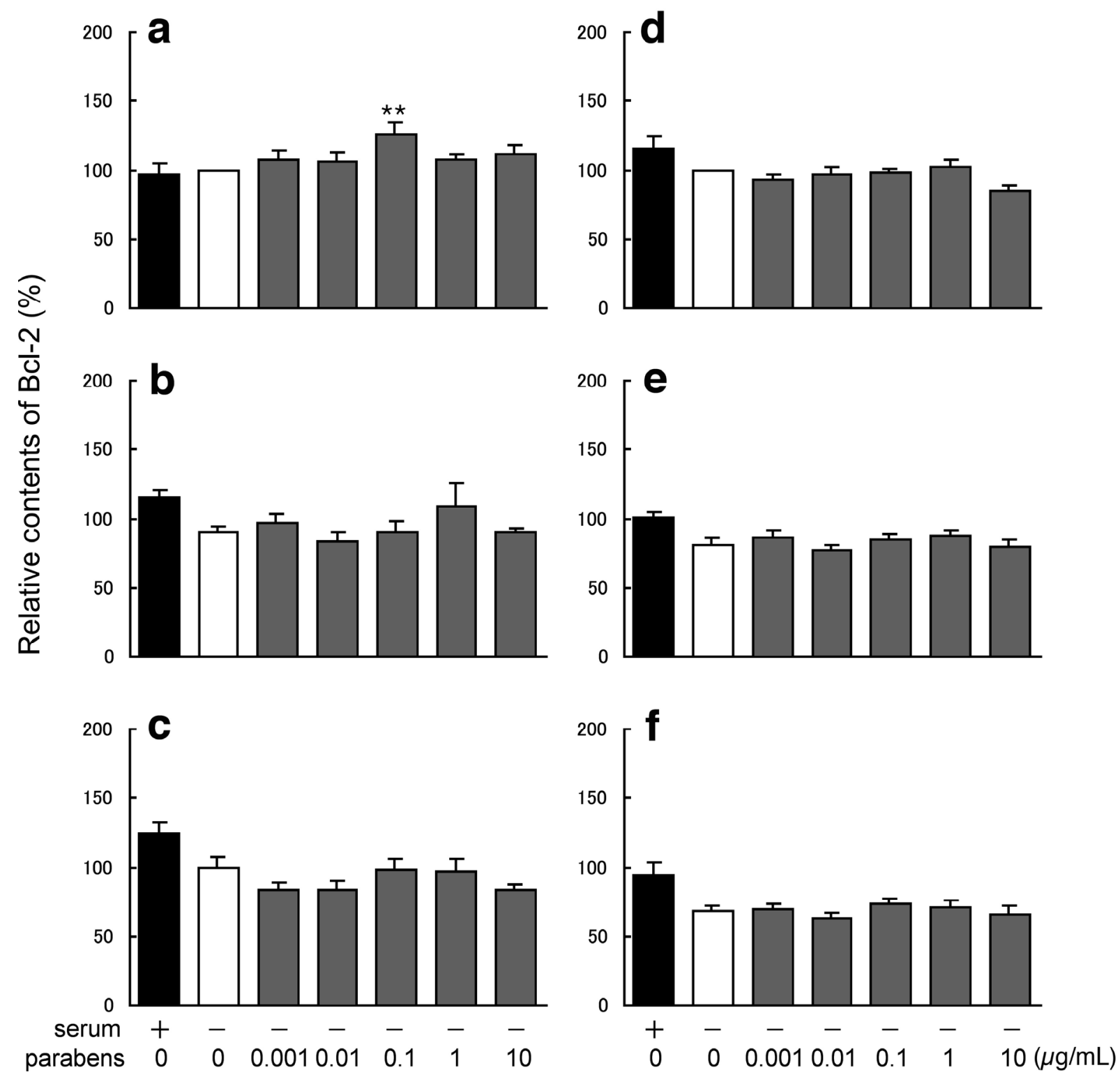

618

619

620

621

622

623

624 
Fig.5

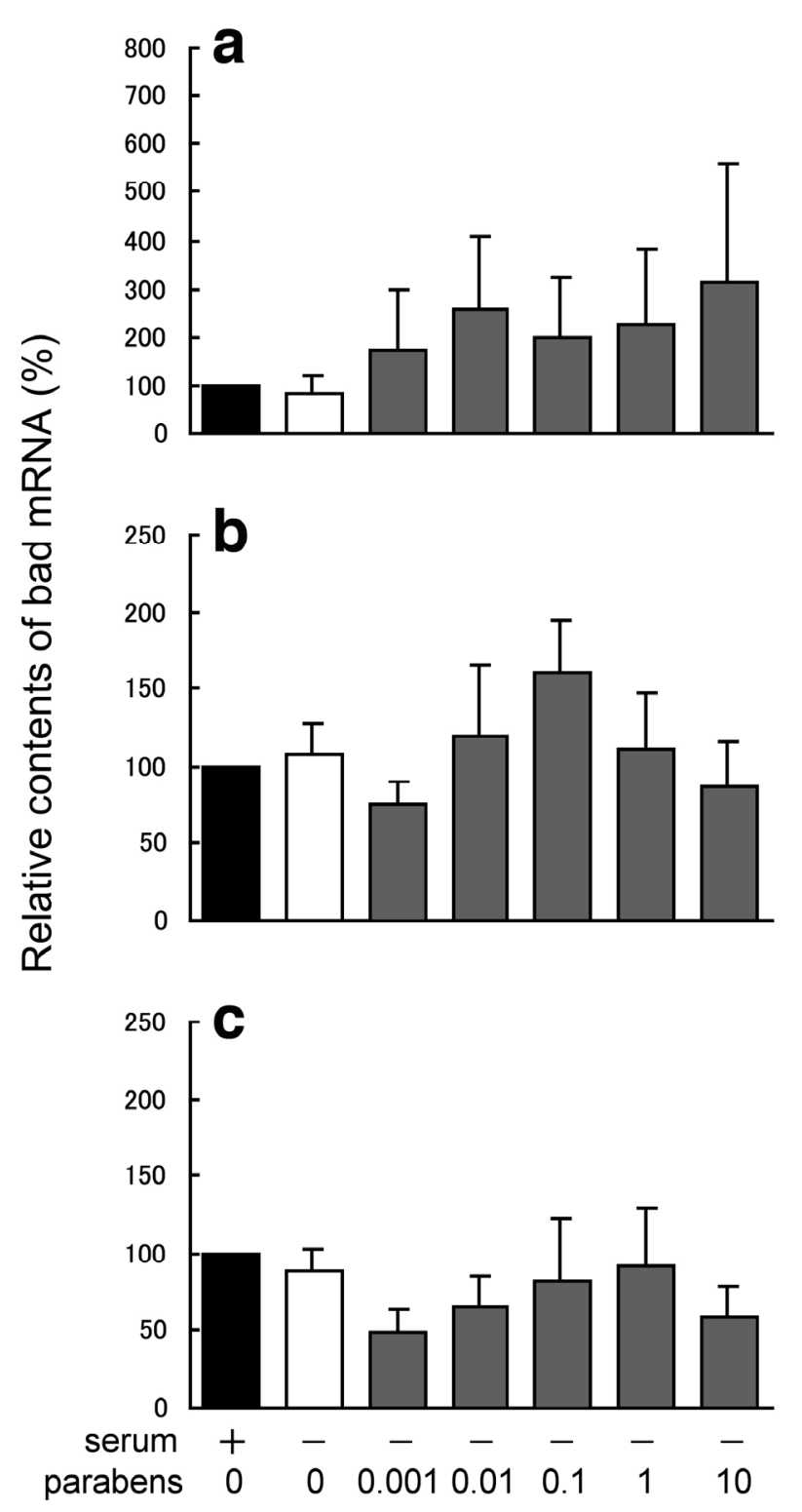

- serum + ethanol

$\square$ serum-free + ethanol (Control)

$\square$ serum-free + parabens
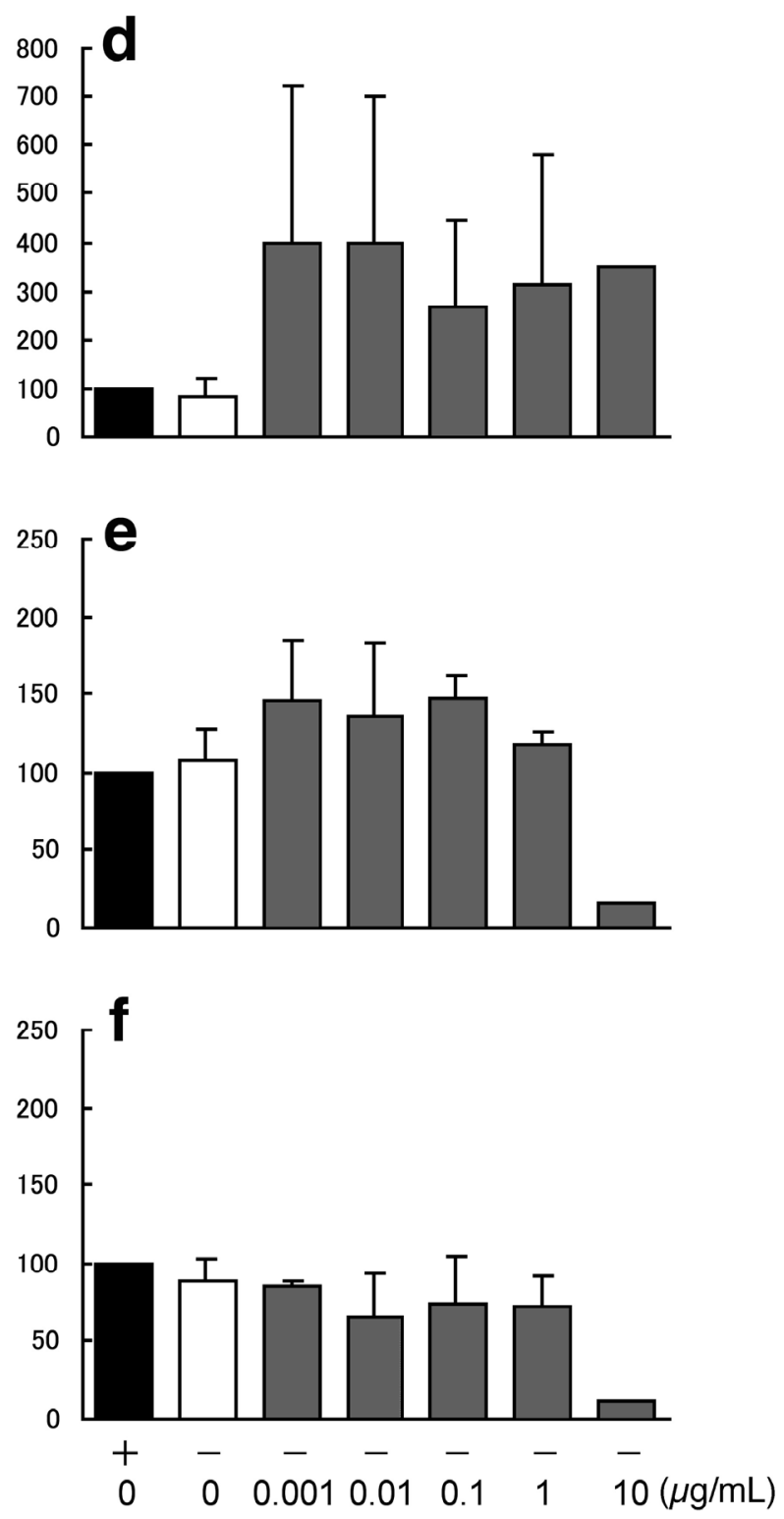

626

627

628

629

630

631

632 


\section{Fig. 6}

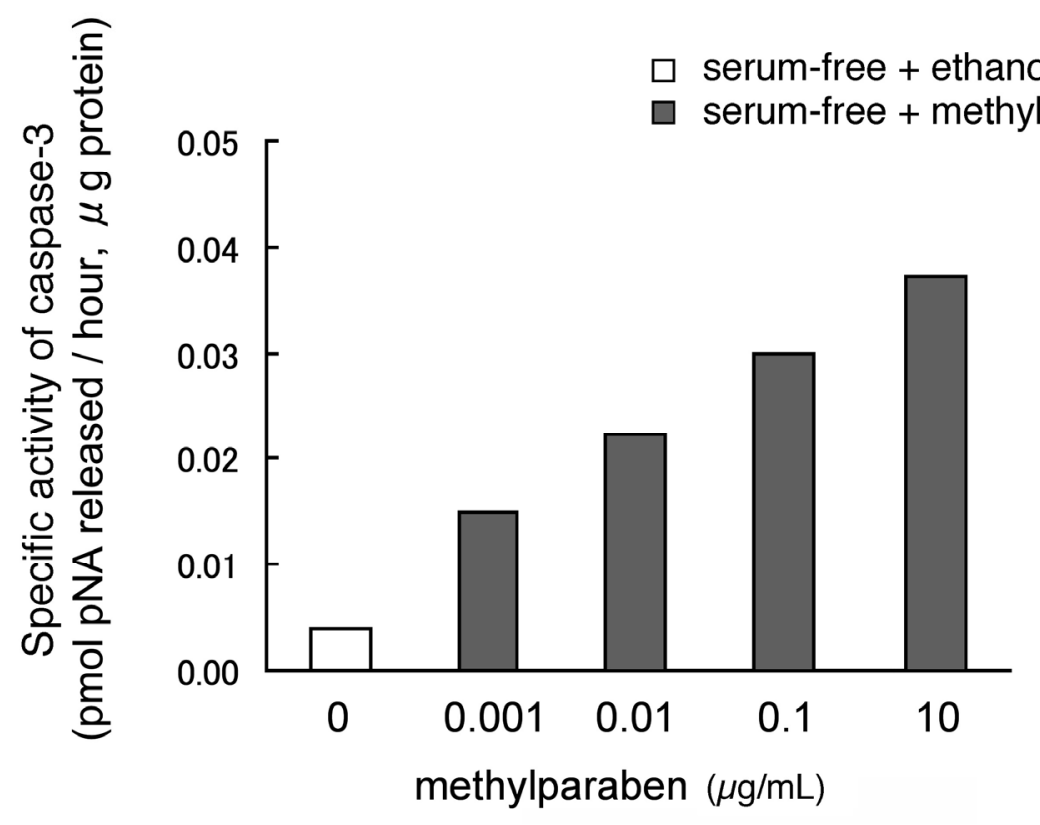

633

634

635 